\title{
Confirmation of the occurrence of teliospores of Hemileia vastatrix in Brazil with observations on their mode of germination
}

\author{
Ronaldo de Castro Fernandes ${ }^{1}$, Harry Charles Evans ${ }^{2} \&$ Robert W. Barreto ${ }^{1}$ \\ ${ }^{1}$ Departamento de Fitopatologia, Universidade Federal de Viçosa, 36570-000, Viçosa, MG, Brazil; ${ }^{2} \mathrm{CAB}$ International, E- \\ UK Centre, Bakeham Lane, Egham, Surrey, TW20 9TY, UK
}

Author for correspondence: Robert W. Barreto, e-mail: rbarreto@ufv.br

\begin{abstract}
The occurrence of teliospores of Hemileia vastatrix in Brazil is confirmed for the first time and clearly documented under light microscopy and SEM. Additionally, voucher specimens of leaves containing sori with germinated and non-germinated teliospores were deposited in a local herbarium (Herbário VIC). The previous publication claiming to provide an account of the occurrence of teliospores of $H$. vastatrix in Brazil did not include appropriate images or an indication of voucher specimens. Observations during 2006, at a site in the Zona da Mata coffee-growing region of Minas Gerais, Brazil, revealed the presence of teliospores during the winter months (JulySeptember), probably triggered by the fall in temperature and decreasing rainfall immediately prior to and during this period. A significant proportion of these teliospores exhibited abnormal germination: the number of promycelial cells varying from three to seven, with or without the production of sterigmata. Basidiospores were variable in size and shape, possibly indicating genetic instability, and this is discussed in relation to the life-cycle of coffee leaf rust.
\end{abstract}

Keywords: Abnormal germination, coffee leaf rust, genetic instability, rust lineages, SEM studies.

\section{RESUMO}

Confirmação da ocorrência de teliosporos de Hemileia vastatrix no Brasil com observações sobre a sua germinação

A ocorrência de teliósporos de Hemileia vastatrix no Brasil é confirmada e, pela primeira vez, claramente registrada sob microscopia de luz e MEV. Além disto, amostras representativas de folhas de cafeeiro apresentando soros contendo teliósporos germinados e não germinados foram depositadas em herbário (Herbário VIC). A publicação anterior onde a ocorrência de teliósporos de $H$. vastatrix no Brasil é supostamente reportada pela primeira vez não incluiu um registro fotográfico adequado ou a indicação do depósito de um espécime representativo. Observações efetuadas no ano de 2006 na Zona da Mata de Minas Gerais, Brasil, revelaram a presença de teliósporos durante os meses de inverno (julho-setembro). Sua formação foi provavelmente desencadeada pela diminuição da temperatura e pluviosidade baixa antes e durante este período. Uma proporção significativa dos teliósporos exibiu uma germinação anormal: o número de células do promicélio variou de três a sete e a produção de esterigmas era variável ou mesmo ausente. Basidiósporos variaram em forma e tamanho, possivelmente indicando uma instabilidade genética e isso é discutido em relação ao ciclo de vida da ferrugem do cafeeiro. Palavras-chave: Germinação anormal, ferrugem do cafeeiro, instabilidade genética, linhagens de ferrugens, MEV.

Coffee is one of the most important agricultural products in the world in economic terms, being second only to petroleum among the global commodities (Kushalappa \& Eskes, 1989a; Vega et al., 2003). Brazil is the world's leading producer and exporter of coffee and the second largest consumer (ABIC, 2007). Coffee leaf rust is the most destructive disease of this crop and the major constraint to production worldwide (Agrios, 2005), having caused severe economic impacts in plantations of Coffea arabica L. wherever it is established. It is frequently cited as an example of a devastating fungal disease which can change

Part of the Master Thesis of the first author. Universidade Federal de Viçosa. Viçosa MG. 2007. the socio-economic structure of a country, as in Ceylon (now Sri Lanka) in the $19^{\text {th }}$ century (Large, 1940; McCook, 2006). It reached the east coast of Brazil in 1970, presumably from West Africa (Medeiros, 1970), and by 1984 it had spread to all the coffee-producing countries in Latin America (Kushalappa \& Eskes, 1989b).

The etiological agent of this disease, Hemileia vastatrix Berk. \& Br., was first investigated by Ward (1882a, b) and, despite more than 120 years of research since this pioneering and seminal study, some fundamental aspects of this rust species still remain obscure, particularly relating to its life-cycle. An outline of the life-cycle of $H$. vastatrix was proposed by Ward (1882b) and, essentially, this still remains the accepted model (Agrios, 2005; Ayres, 2005). According to this interpretation, the orange lesions on coffee 
leaves represent the asexual stage (anamorph) of the fungus. Groups of thick-walled, half rough-half smooth, reniform urediniospores are produced on suprastomatal uredinia forming powdery orange masses. Such spores function as dispersal, survival and infection structures. Occasionally, smooth, orange and thin-walled sexual spores (teliospores) are formed within the lesions and germinate to produce smaller, hyaline meiospores (basidiospores). Infectivity of basidiospores to coffee has not been demonstrated and, so far, no alternate host has ever been found; although Rayner (1972) posited that the fungus is heteroecious and, based on Transchel's Law, that the alternate host is an orchid (Rodrigues, 1990).

Nevertheless, alternative hypotheses need to be tested in order to elucidate the life-cycle of $H$. vastatrix, allowing for a better understanding of the pathogen's evolution. This would have direct implications for disease management, particularly in redirecting the strategy of breeding for resistance to the rust. The present study forms part of a research program undertaken to determine the form and function of the various spore stages described, thus far. Here, we report preliminary findings on the occurrence of teliospores in Brazil - where, previously, such data have been lacking or unsubstantiated - and the subsequent attempts to interpret the role of these spores in the life-cycle of coffee leaf rust.

Samples were mainly collected from a commercial coffee farm in the municipality of Coimbra ( $c a .720$. m.a.s.l.) in the Zona da Mata, one of the main coffeeproducing regions of the Brazilian state of Minas Gerais. Collections were made from July to December 2006. Leaf samples, bearing a high density of rust pustules and with no macroscopic evidence of mycoparasitism or infestation by fungivorous dipteran larvae, were transported to the laboratory at the Universidade Federal de Viçosa (UFV) in plastic bags and examined while still fresh, using a dissecting microscope (Olympus SZ 11). Only leaves with healthy (non-parasitized) pustules were selected for further analysis. A minimum of 30 leaves and up to 100 were scanned during each monthly sample. The number of leaves having $H$. vastatrix teliospores was recorded. Leaves containing a high density of teliospores were selected for further study using both optical and scanning electron microscopy (SEM). Selected leaves of $C$. arabica showing $H$. vastatrix colonies with various stages of teliospore development were dried in a plant press and deposited in the herbarium at UFV, namely: VIC 30613, Coimbra, state of Minas Gerais, $5^{\text {th }}$ July 2006; VIC 30614, ibid, $17^{\text {th }}$ July 2006; VIC 30615, Guaraciaba, state of Minas Gerais, $10^{\text {th }}$ September, 2005; VIC 30616, Manhuaçú, state of Minas Gerais, $5^{\text {th }}$ October 2006.

For light microscopy studies, slides were mounted in lactofuchsin and observations were made and images were taken with an Olympus BX 50, fitted with an Olympus SC 35. SEM studies were performed as follows: $0.5 \mathrm{x}$ $0.5 \mathrm{~cm}^{2}$ fragments from freshly-collected leaves bearing teliospores were immersed in 5\% glutaraldehyde prepared in $0.1 \mathrm{M} \mathrm{C}_{2} \mathrm{H}_{6} \mathrm{AsO}_{2} \mathrm{Na}$ buffer, $\mathrm{pH} 6.8$ (1:1). The samples were stoppered and kept in a fridge at $5^{\circ} \mathrm{C}$, for 24 hours, then washed six consecutive times with a mixture of buffer and distilled water (1:1), and subsequently dehydrated by successive transfer in a graded series of ethanol solutions $(30 \%, 50 \%, 70 \%, 85 \%, 95 \%$ and $100 \%)$, where they were left for $10 \mathrm{~min}$ in each solution. In order to guarantee complete dehydration of the tissues, the samples were also immersed twice in $100 \%$ ethanol. Samples were then dried in a critical point dryer (BAL-TEC ${ }^{\circledR}$ model CPD 030) using liquid $\mathrm{CO}_{2}$ as transition fluid. After drying, the samples were coated with gold ( 40 or $60 \mathrm{~nm}$ thickness) in a sputter coater (BAL-TEC ${ }^{\circledR}$ model SCD 050) and examined using a Zeiss ${ }^{\circledR}$ LEO 1430 VP.

Monthly frequency of occurrence of teliospores at Coimbra was of $20 \%$ in July, $15 \%$ in August, and $5 \%$ in September. No teliospores were found in samples collected at this locality from October to December. Although the survey for teliospores covered only part of the year, it showed that teliospore incidence was highly variable, ranging from total absence to occurrence on up to $20 \%$ of leaves; it tended to gradually decrease in frequency from winter to spring. Earlier ad hoc surveys during April to June in experimental plots at a neighboring municipality (Viçosa) did not reveal the presence of teliospores. Ad hoc collections in other regions of the state of Minas Gerais also yielded specimens bearing teliospores from the municipalities of Alto Caparaó, Araponga, Guaraciaba, Manhuaçú and Viçosa but not from Machado, Patrocínio or Varginha. Nevertheless, collections at the latter were all made either early (May for Patrocínio) or late (December for Machado and Varginha) in the year and it is likely that climate was unfavorable for teliospore production at the time.

Although there is a previous publication reporting the first occurrence of teliospores of $H$. vastatrix in Brazil (Sugimori et al., 1976), the evidence presented in that publication is questionable. A closer examination of their published illustrations (Figure 1) revealed that, although these illustrations are of poor quality, none of the spores have the typical smooth, thin-walled napiform morphology of $H$. vastatrix teliospores. Also, contrary to what was observed in the present work, there is no evidence of promycelia or basidiospores, whereas all the material collected during our study contained germinated teliospores with promycelia and basidiospores. Our interpretation of the structures in Sugimori et al. (1976) is that these represent immature urediniospores of $H$. vastatrix. Unfortunately, Sugimori et al. (1976) did not cite a herbarium deposit, which would have allowed for its re-examination. We conclude, therefore, that the present publication is the first authenticated report of the teliospores of $H$. vastatrix in Brazil (Figures 2 and 3).

Observations from this limited survey in Minas Gerais indicate that teliospores of $H$. vastatrix are not as rare as suggested in the literature. In fact, they are relatively common 

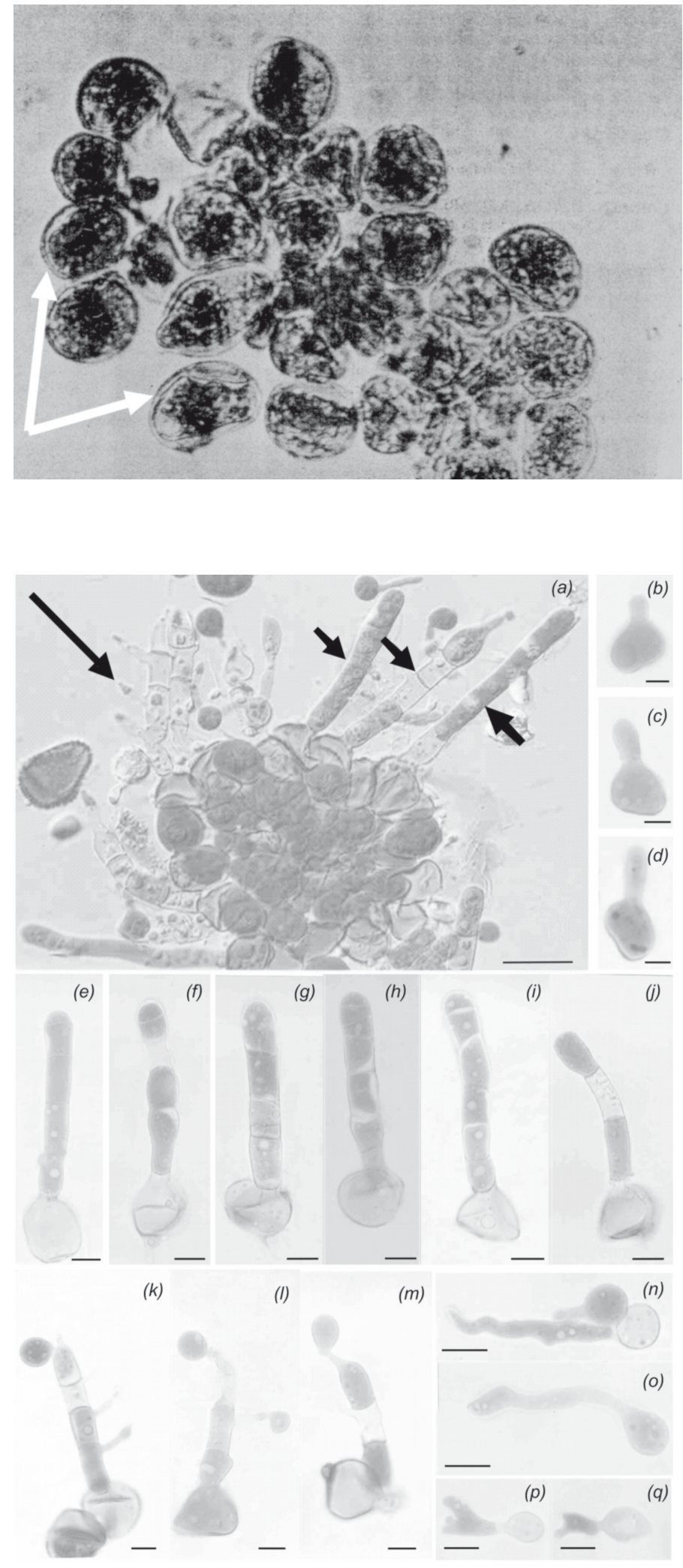

FIGURE 1 - Illustration included in Sugimori et al. (1976) and purportedly showing teliospores of Hemileia vastatrix collected in Brazil. Note relatively thickened walls, signs of echinulation (arrowed) and absence of promycelia. Compare with Figure 2. Reproduced by permission of Summa Phytopatologica.
FIGURE 2 - Germination of teliospores and basidiospores of Hemileia vastatrix. a. general aspect of a sorus, mostly containing teliospores (note echinulate thick-walled urediniospore on the left): typical germination with 4celled promycelium and 4-sterigmata (long arrow) and atypical, 5 to 6-celled promycelium (short arrows) (bar $=30 \mu \mathrm{m}$ ); b-d. initiation of teliospore germination (note oil droplets); e-i. promycelia with 5- 6 cells and without sterigmata; j. 3-celled promycelium; 4-5 sterigmata; k. typical promycelium producing basidiospores; Im. 3-celled promycelia with 1-2 sterigmata producing 1-2 basidiospores; n-q. germinating basidiospores (note formation of appressorium-like structures). b-q. bar $=10$ $\mu \mathrm{m}$. towards the end of the cold season (July-Sept.), although never abundant, and are probably stimulated by changing climatic conditions. Teliospore formation is most likely to be triggered by the low temperatures recorded during this period (ca. 6-11 ${ }^{\circ} \mathrm{C}$ mean min., data ex UFV meteorological station) and the low to moderate rainfall (ca. 7-63 mm/month). With rising 

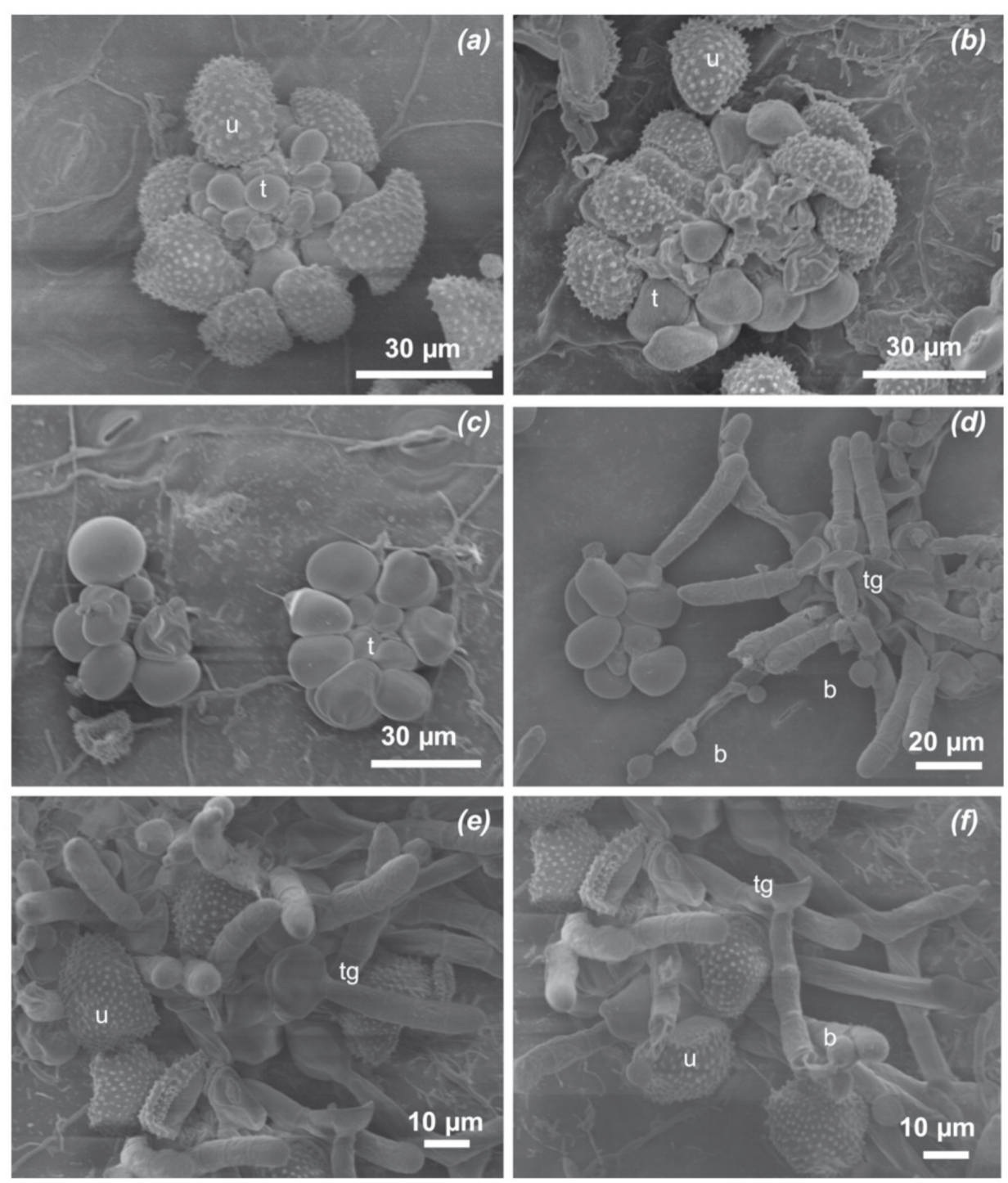

FIGURE 3 - Teliospores and urediniospores of Hemileia vastatrix under SEM: (A-B) immature teliospores $(\mathrm{t})$ grouped and flattened among urediniospores $(\mathrm{u})$; C. sori containing only young teliospores ( $\mathrm{t}$ ) without papillae; D. sori containing mature germinated teliospores and basidiospores (b); E-F. teliospores germinating (tg) amongst urediniospores (u) and basidiospores (b).

temperatures $\left(15-18^{\circ} \mathrm{C}\right.$ mean min.) and increasing rainfall from October to December (ca. 200-230 mm/month), the teliospores disappeared. Nevertheless, their detection on rusted leaves can be difficult since the appearance of telia is macroscopically similar to that of uredinia. Moreover, teliospores and urediniospores are often formed together within a single pustule. Since the teliospores germinate immediately on maturation and in situ, the key to detecting their presence is the occurrence of the characteristic promycelia rising conspicuously from the spore masses. Conversely, urediniospores never germinate within the pustules.

The morphology of the fungal structures observed is as follows: teliospores sub-sphaerical to napiform, pedicelate, with a terminal papilla, $12-27 \times 15-27 \mu \mathrm{m}$, walls smooth, thin, pale yellow, guttulate (oil droplets orange, Figure 2b), germinating in situ and producing a prominent germ tube (the basidium or promycelium); promycelium cylindrical, straight, $20-88 \times 7-12 \mu \mathrm{m}, 0-6$ septate, hyaline, guttulate, smooth-walled, bearing 0-5 sterigmata; basidiospores globose to subglobose, 5-12 $\mu \mathrm{m}$ diam., hyaline, smoothwalled, guttulate, germinating immediately, germ-tubes often swollen or distorted, sometimes with appressorial-like structures (Figure 2n-q).

The presence of more than three septa in the promycelium is abnormal for the Uredinales but relatively frequent for $H$. vastatrix, according to Chinnappa \& Sreenivasan (1965). The variation in basidiospore size observed for our rust specimens was significant and 
may reflect variable numbers of nuclei. Observation of basidiospore nuclei of $H$. vastatrix, treated with a fluorescent stain, indicated that basidiospores may contain up to four nuclei, with some appearing anucleate (R.C. Fernandes, personal observation, 2006). The cytological studies of Vishveshwara \& Nag Raj (1962) and Chinnappa \& Sreenivasan (1968) in India also showed that most basidiospores of $H$. vastatrix had either one or two nuclei and some had up to four-nucleated basidiospores.

Under SEM, it was observed that teliospores are formed in compact groups that are usually flattened amongst the urediniospores (Figure 3a, b, e, f). Occasionally, they are also formed in pustules or teliosori, containing teliospores only (Fig. $3 \mathrm{c}-\mathrm{d}$ ). The occurrence of teliospores either in combination with urediniospores or in teliosori was also observed by Gopalkrishnan (1951), who also noted that immature teliospores are not papillate.

This study provides a more complete view of the stages of the life-cycle of $H$. vastatrix occurring in Brazil and confirms the results of previous work in India. The latter studies also showed urediniospores germinating to form "basidia" (promycelia) producing both sterigmata and basidiospores, the so-called uredinioid teliospores (Rajendren, 1967 a,b): a feature that still has not been reported in Brazil or elsewhere, and which appears to have been dismissed by subsequent investigators. We conjecture that this cycle may represent a recent adaptation which evolved when the wild host of $H$. vastatrix, possibly the tetraploid form of $C$. arabica, emerged from a forest habitat into a new ecosystem with a drier and more seasonal climate, stimulating the development of new strategies for the pathogen in a co-evolutionary process. This may have led $H$. vastatrix to concentrate its energies into a single multifunctional propagule, the uredinioid teliospore, adapted not only for dispersal, survival and infection but also for sexual recombination, as postulated for Maravalia cryptostegiae (Cummins) Y. Ono (Evans, 1993). It is possible that the thin-walled teliospores, with no inherent dormancy, had finally become redundant (or vestigial) and both genetically and morphologically unstable, as indicated by the work presented here.

This suspicion of genetic instability within the teliospores and basidiospores is reinforced by the frequent occurrence of abnormal germination events observed during this study (Figure 2), as well as in previous studies on H. vastatrix in India (Vishveshwara \& Nag Raj, 1962; Chinnappa \& Sreenivasan, 1965). Cytological evidence has demonstrated that basidiospores contain variable amounts of chromatin (Chinnappa \& Sreenivasan, 1965). These authors suggested that this is a result of instability in the meiotic process and, therefore, that the role of teliospores in the life-cycle of coffee leaf rust would be restricted. Pathogenicity tests performed in the past involving the inoculation of coffee plants with basidiospores did not result in infection (Ward, 1882a; Thirumalachar \& Narasimhan, 1947; Gopalkrishnan, 1951). Similarly, our attempts to infect coffee with basidiospores proved to be negative, but these were hampered by the relative scarcity of these spores and the considerable difficulties in collecting sufficient inoculum for meaningful pathogenicity studies (Fernandes, 2007).

Hemileia vastatrix is not the only rust fungus having a cycle in which the teliospores and basidiospores appear to be vestigial, with their functions being transferred to the urediniospores. Evans (1993) also reported similar findings for M. cryptostegiae. This rust produces urediniospores morphologically similar to those of $H$. vastatrix and differs from Hemileia only in the shape of the teliospores. Evans (1993) suggested that these two species were primitive and had close phylogenetic affinities; they might have originated in moist tropical forests, producing only simple, thin-walled teliospores with no dormancy. These ancestral rusts would have been autoecious with unexpanded or only partly expanded life-cycles. This purported phylogenetic affinity has been confirmed recently through molecular systematics (Wingfield et al., 2004; Aime, 2006). These studies further indicate that the genera Hemileia and Maravalia are at the root of the phylogenetic tree of the Uredinales within the family Chaconiaceae and represent the most primitive group within the rust lineages.

Prior to these findings, Hennen \& Figueiredo (1984) presented convincing circumstantial evidence to show that $H$. vastatrix is a primitive autoecious rust lacking pycnial and aecial stages in the life-cycle. Our results lend support to this hypothesis. Further work is in progress to provide definitive proof of the multifunctional role of the urediniospore and its true telioid or sexual nature. This could have profound implications for resistance breeding programs against coffee leaf rust.

\section{ACKNOWLEDGEMENTS}

The authors thank the Conselho Nacional de Desenvolvimento Científico e Tecnológico - CNPq for financial support. SEM studies were performed at the Núcleo de Microscopia e Microanálise - CCB/UFV with guidance from C. A. Vanetti.

\section{REFERENCES}

Agrios GN (2005) Plant Pathology. Amsterdam. Elsevier Academic Press.

ABIC (2007) Estatística - Exportações. http://www.abic.com.br/ estat_exporta_ppaises.html\#topo.

Aime MC (2006) Toward resolving family-level relationships in rust fungi (Uredinales). Mycoscience 47:112-122.

Ayres P (2005) Harry Marshall Ward and the fungal thread of death. Saint Paul MN. APS Press. 
Chinnappa CC, Sreenivasan MS (1965) Cytological studies on germinating teliospores of Hemileia vastatrix. Caryologia 18:625631.

Chinnappa CC, Sreenivasan MS (1968) Cytology of Hemileia vastatrix. Caryologia 21:75-82.

Evans HC (1993) Studies on the rust Maravalia cryptostegiae, a potential biological control agent of rubber-vine weed Cryptostegia grandiflora (Asclepiadaceae: Periplocoideae), in Australia.I: Lifecycle. Mycopathologia 124:163-174.

Fernandes RC (2007) Reavaliação do ciclo de vida de Hemileia vastatrix no Brasil. Dissertação de Mestrado. Universidade Federal de Viçosa. Viçosa MG.

Gopalkrishnan KS (1951) Notes on the morphology of the genus Hemileia. Mycologia 43:271-282.

Hennen JF, Figueiredo MB (1984) The life cycle of Hemileia vastatrix. Simpósio sobre Ferrugem do Cafeeiro. Centro de Investigação das Ferrugens do Cafeeiro. Instituto de Investigação Científica Tropical: Oeiras, Portugal, pp. 47-56.

Kushalappa AC, Eskes AB (1989a) Advances in coffee rust research. Annual Review of Phytopathology 27:503-531.

Kushalappa AC, Eskes AB (1989b) Coffee rust: epidemiology, resistance, and management. Boca Raton FL. CRC Press Inc.

Large EC (1940) The Advance of the Fungi. London. Jonathan Cape.

McCook S (2006) Global rust belt: Hemileia vastatrix and the ecological integration of world coffee production since 1850 . Journal of Global History 1:177-195.

Medeiros AG (1970) Informe sobre Hemileia vastatrix em café na Bahia, Brasil. CEPLAC, Rio de Janeiro.

Rajendren RB (1967a) A new type of nuclear life cycle in Hemileia vastatrix. Mycologia 59:279-285.

Rajendren RB (1967b) Atypical and typical germination of uredinioid teliospores of $H$. vastatrix. Mycologia 59:918-921.

Rayner RW (1972) Micologia, historia y biologia de la roya del cafeto. Publicación Miscelânea. Instituto Interamericano de Ciencias Agrícolas. Turrialba, Costa Rica.

Rodrigues Jr CJ (1990) Coffee rusts: history, taxonomy, morphology, distribution and host resistance. Fitopatologia Brasileira 15:5-9.

Sugimori MH, Soave J, Paradela Filho O, Moraes SA, Ribeiro IJA, Fumiko IM (1976) Constatação de teliósporos de Hemileia vastatrix Berk. \& Br. no Brasil. Summa Phytopathologica 2:299302.

Thirumalachar MJ, Narasimhan MJ (1947) Studies on the morphology and parasitism of Hemileia species on Rubiaceae in Mysore. Annals of Botany 11:77-89.

Vega FE, Rosenquist E, Collins W (2003) Global project needed to tackle coffee crisis. Nature 425:343.

Vishveshwara S, Nag Raj TR (1962) Some abnormalities of teliospore germination in Hemileia vastatrix. Phyton (Argentina) 18:75-79.

Ward MH (1882a) Researches on the life-history of Hemileia vastatrix, the fungus of the "Coffee-leaf Disease". Journal of the Linnaean Society (Botany) 19:299-335.

Ward MH (1882b) On the morphology of Hemileia vastatrix Berk. and $\mathrm{Br}$. (The fungus of the coffee disease of Ceylon). Quarterly Journal of Microscope Science 22:1-11.

Wingfield BD, Ericson L, Szaro T, Burdon JJ (2004) Phylogenetic patterns in the Uredinales. Australasian Plant Pathology 33:327335.

Received 25 July 2008 - Accepted 14 April 2009 - TPP 8085 Associated Editor: Marcos P.S. Camara 